\title{
Kohesi Sosial Masyarakat Kaimana Di Tengah Konflik Papua
}

\author{
Kaimana Community Social Cohesion Amid the Papua Conflict Kanisius Laga
}

\author{
Kanasius Laga Doni ${ }^{1}$, Husain Hamka ${ }^{2}$, Andi Burchanuddin ${ }^{3}$ \\ Email: kanasiuslagadoni95@gmail.com \\ ${ }^{1}$ Program Studi Sosiologi, Fakultas Ilmi Sosial dan Politik, Universitas Bosowa
}

Diterima: 07 Juni 2021 / Disetujui: 20 Agustus 2021

\begin{abstract}
ABSTRAK
Penelitian ini bertujuan untuk mengkaji dan menganalisis Kohesi Sosial Masyarakat Kaimana Di Tengah Konflik Papua. Kegunaan dari penelitian ini adalah untuk menggambarkan bagaimana tindakan sosial masyarakat di kabupaten Kaimana di tengah konflik Papua. Objek penelitian ini adalah stakeholder dan masyarakat kabupaten Kaimana dengan memilih 5 informan. Dengan menggunakan metode kualitatif, dan menggunakan purposive sampling teknik pengambilan sampel sumber data dengan pertimbangan tertentu. Hasil penelitian menunjukan bahwa kesempatan kerja dalam pemerintahan serta kesempatan memperoleh pendidikan masyarakat asli papua dan non papua mempunyai kesempatan yang sama dan selalu menjaga hubungan keharmonisan yang sudah di tanamkan sejak dahulu sehingga isu konflik papua tidak menjadi domain untuk memecah belah persaudaraan yang ada di kabupaten Kaimana. Bentuk kohesi social yang di lakukan adalah dengan cara sikap saling menghargai dan saling menghormati. Masyarakat Kaimana dalam merespon isu rasisme dengan solidaritas yang sangat kuat sehingga menggelar demonstrasi dengan aksi damai serta lebih bijak dan mengedepankan rasa persaudaraan, peran stakeholder sangat di butuhkan terkait perkembangan masyarakat melalui kebijakan atau sosialisai serta himbauan terhadap masyarakat.Dalam hal ini masyarakat dan stakeholder tak dapat di pisahkan melainkan kerja sama sehingga terwujudanya masyarakat kaimana yang sejahtera dan menjauhkan masyarakat dari konflik yang memecah bela masyarakat.
\end{abstract}

Kata Kunci: Kohesi Sosial, Konflik, Papua

\begin{abstract}
This study aims to examine and analyze the social cohesion of the Kaimana people in the midst of the Papua conflict. The purpose of this research is to describe the social actions of the people in Kaimana district in the middle of the Papua conflict. The object of this research is the stakeholders and the community of Kaimana district by selecting 5 informants. By using qualitative methods, and using purposive sampling technique of sampling data sources with certain considerations. The results showed that job opportunities in government as well as opportunities to get education from indigenous Papuans and non-Papuans had the same opportunity and always maintained a harmonious relationship that had been cultivated long ago so that the issue of Papuan conflict did not become a domain to divide the brotherhood in Kaimana district. The form of social cohesion that is done is by means of mutual respect and mutual respect. The Kaimana community in responding to the issue of racism with very strong solidarity so that they held demonstrations with peaceful and wiser actions and prioritizing a sense of brotherhood, the role of stakeholders is very much needed related to community development through policies or socialization and appeals to the community. In this case the community and stakeholders cannot separated, but cooperation so as to create a prosperous community and keep people away from conflicts that divide the defense of the community.
\end{abstract}

Keywords: Social Cohesion, Conflict, Papua

This work is licensed under Creative Commons Attribution License 4.0 CC-BY International license 


\section{A. PENDAHULUAN}

Kabupaten Kaimana merupakan kabupaten hasil pemekaran wilayah Kabupaten Fak-Fak. Kabupaten Kaimana memiliki delapan suku asli Kaimana yakni suku Irarutu, Kuri, Mairasi, Oburau, Medewana, Napiti, Myere, dan Kouwayi. Kondisi adat istiadat di kabupaten Kaimana oleh karena letaknya yang strategis sebagai tempat persinggahan masyarakat dari berbagai daerah telah mendapat pengaruh budaya dari luar (interaksi sosial). Sehingga nilai-nilai adat asli daerah ini telah terakulturasi oleh nilai-nilai budaya sekitar dan menciptakan sebuah kehidupan masyarakat yang multikultural Begitupun kehidupan komposisi pemeluk agama di Kaimana terlihat cukup beragam yakni Islam, Kristen Protestan, Khatolik, Hindu dan Budha. Kondisi kerukunan dan toleransi umat beragama berjalan dengan baik, walaupun mayoritas pendudukannya beragama Kristen Protestan, yang notabenenya masyarakat asli papua

Aksi tersebut spontan dilakukan oleh segenap masyarakat Kaimana baik suku asli Papua maupun suku-suku pendatang yang berada di kabupaten Kaimana. Aksi solidaritas yang berlangsung, didukung penuh oleh Dewan Adat dan Forum Komunikasi Pimpinan Daerah (terdiri dari Bupati, Wakil Bupati, Kapolres, Ketua
DPRD, dan Kejaksaan Negeri). Dalam aksi tersebut tidak ada tindakan anarkis yang berujung ricuh seperti yang terjadi di kabupaten-kabupaten Papua dan Papua Barat lainnya. Aksi ini tidak memberikan dampak bagi kehidupan sosial masyarakat Kaimana.

Dengan melihat fenomena sosial yang terjadi, peneliti merasa tertarik untuk melakukan penelitian tersebut, dengan fokus penelitian sebagaimana rumusan masalah.

Berdasarkan latar belakang masalah maka dapat dirumuskan permasalahan tentang kohesi sosial massyarakat di tengah konflik Papua di kabupaten Kaimana sebagai berikut: Mengapa masyarakat Kaimana tidak terimbas dari konflik Papua?

\section{B. METODE PENELITIAN \\ 1. Jenis Penelitian}

Sesuai dengan masalah yang penulis ajukan, maka penulis menggunakan metode penelitian kualitatif. Yaitu suatu proses penelitian dan pemahaman yang berdasarkan pada metodologi yang menyelidiki suatu fenomena sosial dan masalah manusia (Sugiyono, 2012). Pada pendekatan ini, peneliti membuat suatu gambaran kompleks, meneliti kata-kata, laporan terperinci dari pandangan responden, dan melakukan studi pada situasi alami. Penelitian ini bersifat deskriptif, dimana penelitian deskriptif untuk 
mengeksplorasi dan mengklarifikasi suatu kenyataan sosial di dalam masyarakat.

\section{Lokasi dan Waktu Penelitian}

Penelitian ini dilaksanakan di Kabupaten Kaimana Provinsi Papua Barat. Penelitian ini dilaksanakan terhitung dari perencanaan penelitian, pelaksanaan penelitian, sampai pembuatan laporan penelitian. Penelitian dilaksanakan di bulan Desember 2019 sampai dengan bulan Februari 2020. Tetapi batas waktu tersebut masih bersifat sementara, sehingga jika sewaktu-waktu masih memerlukan data, penulis dapat mengunjungi lokasi penelitian.

\section{HASIL DAN PEMBAHASAN}

Rasa nyaman yang di rasakan oleh masyrakat kaimana di tengah konflik papua tentu tidak lepas dari beberapa hal, diantaranya ialah masyarakat kaimana sejak dulu sudah hidup saling berdampingan dan menghormati satu sama lain antara masyarakat pendatang maupun masyarakat asli papua. Adanya nilai-nilai keharmonisan yang di wariskan oleh leluhur sampai ke generasi saat ini, serta peran stakholder yang sangat penting dalam menciptakan rasa aman bagi masyarakat.

Berdasarkan wawancara yang dilakukan penulis kepada masyarakat kaimana dan stakeholder yang ada, dapat diketahui bahwa Kohesi Sosial Masyarakat Kaimana itu Terbangun dengan baik.
Seperti yang dipaparkan oleh beberapa Responden, sebagai berikut:

\section{Pemerataan peran masyarakat}

"Peluang kerja itu ada ketika ada kursi yang dibutuhkan dan itu terbuka kepada siapa saja yang mempunyai keterampilan dalam bidang-bidang tersebut, (Onesimus. 30).”

"Mengenai kesempatan kerja antara OAP dan non OAP saya kira itu sudah ada peraturannya di mana persen besarnya adalah masyarakat asli, namun jika posisi tersebut atau bidang tersebut tidak dimiliki oleh masyarakat asli, maka masyarakat pendatang boleh mengisinya, (Frengki Furimbe. 38)."

"Kesempatan dalam memperoleh pendidikan di kabupaten Kaiman sangat terbuka bagi masyarakat Kaimana entah pendatang maupun masyarakat asli Papua. Dan saya sangat bersyukur karena ada aturan dari pemerintah untuk memberikan bantuan kepada masyarakat yang ingin melanjudkan pendidikan kejenjang yang lebih tinggi, "(Anselmus Kopong. 53)."

Yang kami presentasikan pekerjaan dalam pemerintahan $40 \%$ bagi yang dari luar papua dan 60\% untuk asli Kaimana. Untuk nmenyikapi kebijakan MENPAN penerimaan pegawai itu lansung di tentukan $80 \%$ OAP dan 20\% Non OAP.Namun sejauh ini kami belum ada peneranpan 
seperti itu, tetapi justru mereka yang datang dari luar apabilah ada formasi-formasi yang diminta dan diharapkan tapi orang asli papua yang tidak punya ijazah atau sertifikasi dalam suatu bidang misalkan guru atau dokter, tidak menutup kemungkinan saudara dari luar papua yang unggul dalam bidang itu mempunyai kesempatan mengisi jabatan itu dan berkompetisi atau ikut melamar, (Ismail Sirfefa. 60)."

\section{Perilaku dan kesadaran masyarkat}

"Selama ini belum pernah ada persoalan antara masyarakat asli dan masyarakat pendatang. Ini menandakan bahwa hubungan antara masyarakat asli dengan masyarakat pendatang terjalin dengan baik, (Onesimus Safuf. 30).”

"Masyarakat Kaimana menanggapi isu tersebut dengan sangat selektif dan mengedepankan rasa toleransi kekeluargaan yang tinggi sehingga aksi demo damai yang berlangsung sangat kondusif tanpa ada yang terprovokasi. Situasi seperti inilah yang saya harapkan untuk terus kita jaga, ketika ada masalah kita terus berpegangan tangan, "(Frengki Furimbe. 38)."

“Kalau untuk saya sebagai pendatang saya tidak terlalu menanggapi masalah itu. kalau untuk masyarakat asli memang sangat kecewa dengan masalah ujaran kebencian itu sehingga mereka menanggapi juga dengan demo, tetapi hanya dengan demo damai saja, (Anselmus Kopong. 53).”

"Rasa kecewa sekaligus sedih yang di rasakan oleh masyarakat kaimana terkait rasisme saya sangat apresiasi terhadap masyarakat kaimana karena merespon isu rasisme itu dengan aksi damai dan saya mendukung itu selama menyampaikan aspirasi mereka dengan aman, (Emilianus.c35).”

"Menurut saya ikatan persaudaran itu masih terjaga dan masih tertanam dalam benak masyarakat asli maupun pendatang. Walaupun terkadang hubungan seketika renggang karena persoalan mabuk berujung perkelahian namun tidak berefek besar karena dari pihak masing keluarga mengambil sikap dengan jalan damai. Jadi menurut saya hubungan kami baik-baik saja kami saling menerima kekurangan dan kelebihan kami, (Romarius Surbay. 28)."

\section{Integrasi sosial}

"Ya. Contohnya dalam hidup beragama masyarakat Kaimana selalu membudayakan untuk ikut berpartisipasi dalam acara-acara keagamaan seperti ketika saudara dari umat muslim merayakan hari kebesaran maka yang yang menjaga keamanan adalah saudara dari non muslim dan begitupun sebaliknya, (Frengki Furimbe. 38)." 
Dari hasil wawancara di atas disimpulkan bahwa, antara keenam informan tersebut mempunyai argumentasi yang cenderung sama bahwa dalam keseempatan kerja, kesempatan memperoleh pendidikan masyarakat asli papua dan non papua di Kabupaten Kaimana mempunyai kesempatan yang sama dan sadar bahwa masyarakat merupakan satu kesatuan yang tak dapat di pisahkan dalam menjaga hubungan keharmonisan antara masyarakat asli Papua maupun non Papua di Kabupaten Kaimana.

Ralf Dahrendorf dalam teori dua wajah consensus dan konflik itu berhubungan secara dialektik. Sebuah masyarakat tidak mungkin mengalami konflik dengan masyarakat lain jika sebelumnya tidak ada consensus.Seperti halnya masyarakat Kaimana tidak ada muncul konflik jika sebelumnya masyarakat kaimana tidak saling mengenal dan hidup bersama.demikian pula, konflik dapat mengantarkan orang kepada terciptanya hubungan harmonis atau konsensus.yang ini kita bisa lihat dari beberapa kutipan wawancara di atas bahwa masyarakat Kaimana sejak dari awal sudah mempunyai nilai dan norma yang baik yang artinya mempunyai kesepakatan bahwa harus hidup saling melengkapi walaupun tidak secara tertulis sehingga ketika konflik seperti hal- nya rasisme di Surabaya mencuat di kabupaten Kaimana hanya di tanggapi dengan menggelar aksi damai kemudian dengan pertemuan antar tokoh masyarakat, tokoh agama, tokoh adat, Pemda Kaimana dan pihak keamanan sehingga terjadinya konsensus yang mengantar masyarakat Kaimana hidup dalam bingkai keharmonisan.

\section{KESIMPULAN DAN SARAN}

Mengapa Kaimana Tidak Terimbas Konflik Papua? bahwa dalam keseempatan kerja dalam pemerintahan serta kesempatan memperoleh pendidikan masyarakat asli papua dan non papua di Kabupaten Kaimana mempunyai kesempatan yang sama dan selalu menjaga hubungan keharmonisan yang sudah di tanamkan sejak dahulu antara masyarakat asli Papua maupun non papua di Kabupaten Kaimana sehingga isu konflik Papua tidak menjadi domain untuk memecah belah persaudaraan yang ada di Kabupaten Kaimana.

\section{DAFTAR PUSTAKA}

Bollen, K. A., \& Hoyle, R. H, 1990: 479504. "Cohesion A Conceptual and Empirical Examination Social Forces".

Dahrendorf, Ralf. 2011. Konflik dan Konflik Masyarakat Industri Sebuah Analisa Kritik, di Terjemakan Oleh Ali Mandan. Jakarta : CV. Rajawali.

Forrest, R. dan A. Kearns. 2001. Social Cohesion, Social Capital and the 
Neighbourhood. Urban Studies, 38(12), 2125-2143.

Jensen, M. C and Meckling, W.H. (1976). Theory of the Firm: Managerial Behavior Agency Costs and Ownership Structure. Journal of Financial Economics, V. 3, No. 4, pp.305- 360. Avalaible from: http://papers.ssrn.com.

Kornblurn. 2003. (Dalam Susan Novri M.A 2004). Sosiologi Konflik Dan IsuIsuKonflik Konteporer. Jakarta: Pustaka Pelajar.

Kulig J, Townshend I, Awosoga O, Fan HY. 2014. Social cohesion and resilience across communities that have experienced a disaster. Natural Hazards. [Internet]. [Diunduh 9 April 2017]. Dapat diunduh di: https://www.researchgate.net/profile/ Olu_Awosoga/publication/268743797 _Social_cohesion_and_resilience_acro ss_communities_that_have_experienc ed_a_disaster/links/56b382e308ae1f8a a4534b03.pdf

Ritzer, George dan Doglas J. Goodman, 2005 “ Teori Sosiologi Modern, Edisi Keenam”, Kencana: Jakarta.

Sugiyono, 2012 "Memahami Penelitian Kualitatif", Alfabeta: Bandung.

Taylor E, S., 2009 "Psikologi Sosial", Jakarta: Kencana. 